Canadian University Music Review

Revue de musique des universités canadiennes

\title{
Response to Lynn Cavanagh
}

\section{Harald Krebs}

Volume 22, numéro 2, 2002

URI : https://id.erudit.org/iderudit/1014504ar

DOI : https://doi.org/10.7202/1014504ar

Aller au sommaire du numéro

\section{Éditeur(s)}

Canadian University Music Society / Société de musique des universités canadiennes

ISSN

0710-0353 (imprimé)

2291-2436 (numérique)

Découvrir la revue

Citer ce document

Krebs, H. (2002). Response to Lynn Cavanagh. Canadian University Music Review / Revue de musique des universités canadiennes, 22(2), 27-29.

https://doi.org/10.7202/1014504ar
Résumé de l'article

La monographie inusitée de Krebs démontre que l'écriture sur la théorie musicale pure demeure une entreprise indispensable, en particulier dans le domaine relativement négligé du rythme. Mais cela, à la condition que le lecteur prenne une part active à la lecture et qu'il connaisse déjà les mécanismes à l'œuvre dans la musique. Les résultats de cette monographie sont altérés par la perpétuation de la figure de l'artiste incompris et malheureux comme indice de la signification extramusicale que Schumann associait à la dissonance métrique. Le premier mouvement de la Troisième Symphonie de Schumann fait l'objet d'une analyse complémentaire à l'essai. Cette analyse, basée sur l'histoire des idées, suggère que la dissonance métrique de ce mouvement est employée pour réinterpréter un emblème du passé afin d'évoquer une vision de l'avenir.
All Rights Reserved (C Canadian University Music Society / Société de musique des universités canadiennes, 2003
Ce document est protégé par la loi sur le droit d'auteur. L'utilisation des services d'Érudit (y compris la reproduction) est assujettie à sa politique d'utilisation que vous pouvez consulter en ligne.

https://apropos.erudit.org/fr/usagers/politique-dutilisation/ 


\section{RESPONSE TO LYNN CAVANAGH}

\section{Harald Krebs}

I have sometimes worried that by couching Fantasy Pieces in the form of a Schumannesque dialogue, I have laid myself open to the danger of not being taken seriously. Your long and detailed review essay definitely does take the book seriously, for which I am grateful. I am delighted that you have meticulously critiqued not only the theoretical and analytical aspects of the book, but also the more fanciful elements, and that, while you show appreciation for the latter, you also find the theory and the analytical approach valuable.

Your essay has drawn my attention to some points that I had not previously considered. For example, I should have clarified my use of the loaded word "narrative." My conception of "metrical narrative" is not linked with my attempts to grapple with the extramusical meaning of metrical dissonance; I do not mean to imply that my metrical narratives are actual "stories" that can be mapped onto some extramusical narrative. Although I sometimes use extramusical terms to describe them (so as to encourage the reader to keep in mind that the dissonances are more than dry analytical constructs), my metrical narratives function in purely musical terms. By the term "metrical narrative" I mean a musical "plot" (a sequence of events) within which the various metrical states act as characters; they undergo particular "experiences" and are "developed" as would be the characters in a story. This idea of a metrical narrative is most overt in the section of the "Carnaval des Analyses" entitled "Mètres Dansants," in which the various metrical dissonances appear as literal characters, but it underlies all of my large analyses. In short, I did mean to "evoke the idea that music-compositional techniques may be like methods of storytelling" (to use your wording). I am still not convinced that I should therefore have used the cumbersome term "metrical narratography"-but I should at least have explained more fully what I meant by "metrical narrative."

You point out that in my discussions of the meaning of metrical dissonance, I almost always link dissonance with Schumann's illness and other negative states-although, with admirable fairness, you admit that I at least mention the possibility of other meanings. I am aware that Fantasy Pieces does not exhaust the difficult issue of meaning. You may well be right in arguing that Schumann's metrical dissonances may, more frequently than I indicate, have positive connotations, and that they may be linked with ideas that I did not consider in Fantasy Pieces. Your explication of the first movement of the Third Symphony, based on notions that were definitely important to Schumann, is particularly persuasive in connection with this overtly public work. In small forms like piano pieces and Lieder, such politico-philosophical interpretations might turn out to be less convincing. In the Faschingsschwank, there is room for such an interpretation (along with the others that you mention); in most of Schumann's smaller, more personal and private works, however, I find interpretations based on his various personal conflicts to be most compelling.

You raise an objection to one of the fictional, "novelistic" episodes in Fantasy Pieces-the conclusion of Chapter 3. Before I address your remarks about this episode, I must make a few general comments about the novelistic 
aspects of the book. Although some of the events that frame the theoretical discussions are imaginary, I made an effort to remain faithful, if not in letter, then at least in spirit, to what is known about Schumann's final years. There is, of course, no evidence that he ever indulged in long internal dialogues involving Florestan and Eusebius, but since he was taciturn and often withdrew into himself, it is not impossible that such internal dialogues could have taken place. (I do not, of course, believe that these dialogues would actually have involved detailed imaginary discussions of metrical dissonance!) The psychotic episode in Chapter 3 is my closest approach to pure fiction; there is no indication that Schumann suffered from such attacks before his committal to Endenich (although he definitely did once he was there). Again, however, it is not impossible that such episodes could have occurred shortly before his incarceration, when he was in a very excitable and fragile condition.

Your objection to this scene relates, of course, not to its authenticity, but to the implication that Schumann's healthy, artistic fancifulness and the illness that took his life existed along the same continuum. You read this implication into my direct juxtaposition in Chapter 3 of Schumann in a mood of "whimsy" (imagining his Davidsbündler characters making analytical observations on his music) and Schumann in a helpless, psychotic state, and also into my inclusion in this chapter of a "re-vision" of an experience from the early part of Schumann's career. With respect to the "re-vision," I imagined that a hallucination that occurred after an internal dialogue about the music of Paganini could well have incorporated a distorted version of an earlier, more innocuous vision involving that composer. ${ }^{1}$ Furthermore, I did not think of the fictional internal dialogues as products of Schumann's whimsy (the occasional humour notwithstanding); I imagined Schumann in one of his lonely, silent phases, inaccessible to external communication, but listening to voices within. Given this less benign view of the imagined dialogues, the juxtaposition of a dialogue with a psychotic outburst would not result in the implication that you mention.

Although I did not plan to imply a continuity between Schumann's earlier and final conditions, I do believe that the notion of a connection between them cannot be rejected. You mention Daverio's argument that Schumann died of syphilis. Another recent Schumann biographer, however, has questioned the syphilis diagnosis and has suggested that Schumann may, throughout his compositional career, have suffered from bipolar disorder, involving alternating manic and depressive phases. ${ }^{2}$ There will probably never be solid proof either for the syphilis, nor for the bipolar disorder diagnosis. The bottom line is that we still do not know the exact nature of Schumann's final illness, and that we therefore cannot firmly support nor definitively refute hypotheses about how his earlier condition related to his final one.

1 The breaking of the mirror with which this fictional scene culminates, by the way, is also an allusion to something from the earlier part of Schumann's creative career, namely to a climactic scene in his opera Genoveva.

2Erik Jensen, "Schumann at Endenich II: Buried Alive," Musical Times 139, no. 1862 (April 1998): 19-23. 
I tried to make Fantasy Pieces as clear and accessible as possible-but I have learned from your review, and from the remarks of my students, that the book is not as easy to read as I expected it would be. On the other hand, I have heard from students that the fanciful elements (for example, the dialogue format and the coffee bean diagrams) simplified the reading experience for them and made it more enjoyable. Your review suggests that your experience was similar. I continue to hope that the fantastic, Schumannesque aspects of the book will encourage readers to stay with the book-as Florestan stays with the "manuscript" - when frustration sets in.

\begin{abstract}
Krebs's unusual monograph demonstrates that the writing of pure music theory remains an essential enterprise-particularly in the relatively neglected rhythmic domain - but only if the reader undertakes active reading and has prior knowledge of how the music goes. Within the monograph, perpetuation of the image of the misunderstood and suffering artist as a clue to the extramusical meaning Schumann associated with metrical dissonance leads to biased results. This essay's supplementary analysis of the first movement of Schumann's Symphony No. 3, informed by the history of ideas, proposes that in this movement metrical dissonance is used to reinterpret an emblem of the past so as to convey a vision of the future.
\end{abstract}

\title{
Résumé
}

La monographie inusitée de Krebs démontre que l'écriture sur la théorie musicale pure demeure une entreprise indispensable, en particulier dans le domaine relativement négligé du rythme. Mais cela, à la condition que le lecteur prenne une part active à la lecture et qu'il connaisse déjà les mécanismes à l'œuvre dans la musique. Les résultats de cette monographie sont altérés par la perpétuation de la figure de l'artiste incompris et malheureux comme indice de la signification extramusicale que Schumann associait à la dissonance métrique. Le premier mouvement de la Troisième Symphonie de Schumann fait l'objet d'une analyse complémentaire à l'essai. Cette analyse, basée sur l'histoire des idées, suggère que la dissonance métrique de ce mouvement est employée pour réinterpréter un emblème du passé afin d'évoquer une vision de l'avenir. 